notoriously prone to government supervision and delay. Even if Musk runs a lean manufacturing shop, he will face regulatory requirements and other obstacles imposed by government agencies and will need more people to deal with the red tape.

\title{
Limited market
}

Then there is the competition. Musk has his eye on a key NASA contract, details of which are expected to be announced this month, to provide a commercial cargo delivery service to the International Space Station. It could be worth up to $\$ 200$ million over several years, and Musk says he will pursue it vigorously. But so will every other rocket company.

What's more, the overall market for rocket launches remains limited. Forecasters predict only 15 to 20 commercial launches a year, worldwide, for the foreseeable future. And even if space tourists continue to pay $\$ 20 \mathrm{mil}-$ lion for a ride into orbit, as they have done in the past to visit the space station, the number

"One of my core beliefs is that we should be a spacefaring civilization." - Elon Musk of tickets is likely to be limited.

Musk has heard all of this, and hopes to shake things up anyway - which, given his wealth, isn't entirely out of the question. He is also good with politicians and the press, managing to come across as both guileless and smart. He had the sense to hire experienced rocket engineers to build Falcon. And he's not afraid to go to court when he thinks the established rocket manufacturers are engaged in unfair trade practices. In October, he sued Boeing and Lockheed Martin in an attempt to block a proposed merger of their Atlas and Delta rocket programmes that would better position them to win government launch contracts. "Mr Musk knows how to take care of himself," says McKinney.

The real test will be his staying power. If the first Falcon blows up, Musk has said he will try at least two more times before giving up. If it's successful, the second launch will be in March. If things are still going well at that point, he plans to court outside investors to raise a further $\$ 100$ million to build his larger rockets. If none steps forward, he adds, he will put the money up himself.

Musk says he got into rocketry because "one of my core beliefs is that we should be a space-faring civilization". Elias of Orbital Sciences sounds sincere when he wishes him luck. But he says: "Nothing in the laws of physics and very little in the laws of economics gives me hope."

\section{IN BRIEF}

VACCINE BUYOUT In the latest evidence of consolidation in the vaccine industry, the Dutch biotechnology firm Crucell agreed last week to buy the Swiss vaccines company Berna Biotech for $€ 381$ million (US $\$ 449$ million). The all-share offer, expected to be launched in mid-December, will value Berna shares at a premium of $27 \%$ on their closing price on 30 November, the day before the deal was made public. The acquisition creates a company big enough to compete with large vaccine units such as those at Sanofi-Aventis, GlaxoSmithKline and Chiron, which is being acquired by Novartis.

GOING GREEN BP, Europe's leading oil company, plans to double its investment in alternative energy, spending up to US $\$ 8$ billion over ten years on power generation from solar, wind, hydrogen and combined-cycle-gas-turbine sources. The company last week launched a new unit, BP Alternative Energy, to manage the programme. It predicted that the business could generate revenues of $\$ 6$ billion annually within a decade. The new business unit will employ some 2,500 people globally.

LUCRATIVE LICENCE An Alabama biotechnology firm has licensed a drug in early clinical trials to Roche in a deal potentially worth more than half a billion dollars. BioCryst Pharmaceuticals of Birmingham said last week that the Swiss drug-maker will pay it $\$ 25$ million up front for worldwide rights to BCX-4208, a drug intended to prevent transplant rejection and to treat patients with autoimmune diseases. Payments by Roche for future milestones could reach $\$ 530$ million. BioCryst shares surged $37 \%$ after the deal was announced.

\section{MARKET WATCH}

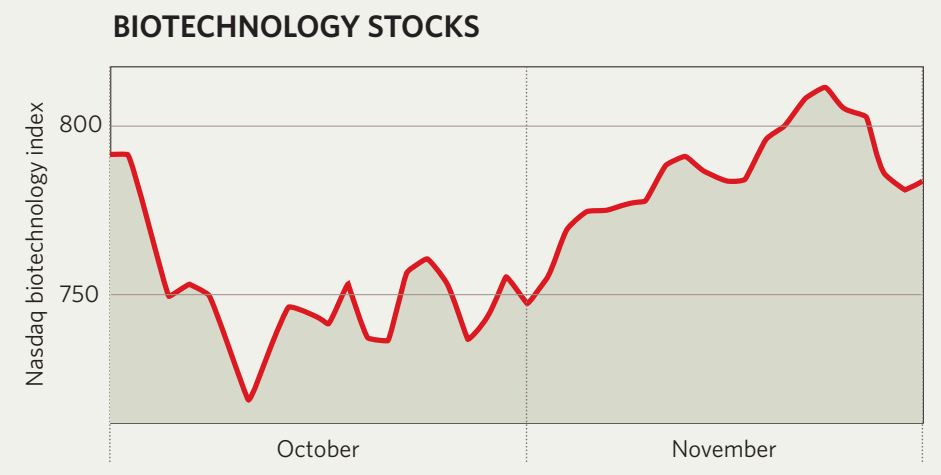

This week Wood Mackenzie, an Edinburghbased research and consulting firm, reviews recent trends in biotechnology stocks.

The Nasdaq biotechnology index fell sharply in early October, losing $9 \%$ of its value following a three-month rally. The decline was influenced by industryspecific events, but also by broad market trends, with the fall being mirrored by other, more general indices. The index recovered to end the period just $0.7 \%$ down, driven by licensing deals as well as strong earnings for the year's third quarter reported in November. All told, the index is up $3.6 \%$ on the year to date.

Clinical-trials failures contributed to the October fall: Human Genome Sciences of Rockville, Maryland, saw its shares plunge $45 \%$ after clinical results showed that its antibody drug candidate LymphoStat-B was ineffective in treating lupus. The drug later partially redeemed the company's share value with encouraging clinical-trials results for rheumatoid arthritis, limiting the loss over the period to $35 \%$. NABI Pharmaceuticals of Boca Raton, Florida, rode out the early fall only to take a $74 \%$ nosedive in share value in early November after poor clinical-trials results halted further development of its StaphVax vaccine to prevent dangerous bacterial infections.

The market recovery was supported by deal-making activity. Early last month, Pain Therapeutics of South San Francisco entered a strategic alliance valued at more than $\$ 400$ million with King Pharmaceuticals of Bristol, Tennessee, to develop an addiction-resistant narcotic painkiller. And in late November, Incyte Pharmaceuticals of Wilmington, Delaware, signed a broad research and development agreement worth up to $\$ 800$ million with drug giant Pfizer. Despite the November surge, the Nasdaq biotechnology index has significantly underperformed compared with wider market indices in the past month.

www.woodmac.com 